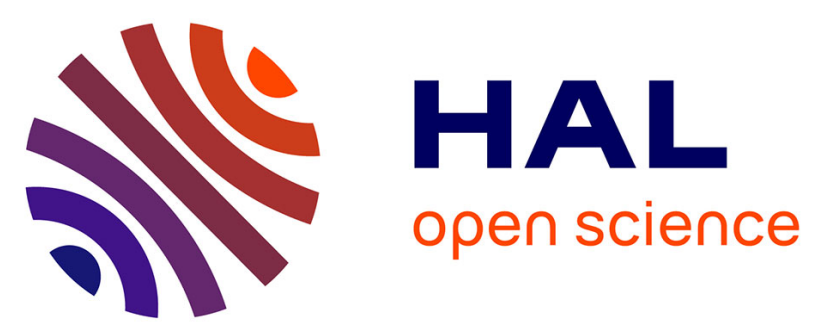

\title{
Real-Time Detection of Gas-Phase Organohalogens from Aqueous Photochemistry Using Orbitrap Mass Spectrometry
}

\author{
Marie Roveretto, Mingchan Li, Nathalie Hayeck, Martin Brüggemann, \\ Corinne Emmelin, Sébastien Perrier, C. George
}

\section{To cite this version:}

Marie Roveretto, Mingchan Li, Nathalie Hayeck, Martin Brüggemann, Corinne Emmelin, et al.. Real-Time Detection of Gas-Phase Organohalogens from Aqueous Photochemistry Using Orbitrap Mass Spectrometry. ACS Earth and Space Chemistry, 2019, 3 (3), pp.329-334. 10.1021/acsearthspacechem.8b00209 . hal-02096013v2

\section{HAL Id: hal-02096013 \\ https://hal.science/hal-02096013v2}

Submitted on 29 Jan 2020

HAL is a multi-disciplinary open access archive for the deposit and dissemination of scientific research documents, whether they are published or not. The documents may come from teaching and research institutions in France or abroad, or from public or private research centers.
L'archive ouverte pluridisciplinaire HAL, est destinée au dépôt et à la diffusion de documents scientifiques de niveau recherche, publiés ou non, émanant des établissements d'enseignement et de recherche français ou étrangers, des laboratoires publics ou privés. 


\section{Real-time detection of gas-phase organohalogens}

\section{from aqueous photochemistry using Orbitrap Mass}

\section{Spectrometry}

Marie Roveretto ${ }^{\dagger}$, Mingchan Lit, Nathalie Hayeck ${ }^{\dagger,+}$, Martin Brüggemann ${ }^{\dagger, ~}{ }^{\star}$, Corinne Emmelin ${ }^{\dagger}$, Sébastien Perrier ${ }^{\dagger}$, Christian George ${ }^{* *}$

†Univ Lyon, Université Claude Bernard Lyon 1, CNRS, IRCELYON, F-69626, Villeurbanne, France

Now at the Chemistry Department, Faculty of Arts and Sciences, American University of Beirut, Beirut, Lebanon

${ }^{\&}$ Now at the Leibniz Institute for Tropospheric Research (TROPOS), Permoserstr. 15, 04318 Leipzig, Germany

\section{KEYWORDS}

Sea surface microlayer-halide - 4-benzoylbenzoic acid -halogenated organic compounds - APCI Orbitrap - online mass spectrometry 


\begin{abstract}
Marine short-lived halogenated compounds, emitted from algae, phytoplankton and other marine biota, affect significantly both the troposphere and the stratosphere. Here we show that such compounds might also be photochemically produced through photosensitized reactions in surface water. Gas-phase products were detected and identified by high-resolution mass spectrometry, more particularly by means of an atmospheric pressure chemical ionization (APCI) source coupled to an Orbitrap mass spectrometer. Under simulated solar irradiation, halogenated organic compounds were produced and detected in the gas phase when a proxy of dissolved organic matter, i.e., 4-benzoylbenzoic acid, was excited into its triplet state. We present a mechanism explaining the formation of a variety of such halogenated compounds. These photochemical reactions take place at the air/sea interface and are, therefore, a potential source of short-lived halogenated compounds in the atmosphere, participating in the tropospheric halogen cycle.
\end{abstract}


Aerosols, cloud droplets, lakes, rivers, and oceans offer a vast surface area for the exchange of chemical species between the aqueous phase and the atmosphere. Oceans, covering about $70 \%$ of the Earth's surface, are among the most important surfaces for such exchanges. The top 1 to 1000 $\mu \mathrm{m}$ of the sea surface, called sea surface microlayer (SML), concentrates many chemical compounds compared to the sub-surface water. ${ }^{1}$ Amino acids, proteins, fatty acids, lipids, phenols, humic substances, and microorganisms accumulate in the SML, leading to distinct physical, chemical and biological properties that are quite different from the underlying bulk water. These compounds are typically released from natural sources, such a cell lysis, and are transferred to the surface by diffusion and rising bubbles..$^{2-4}$ Besides the ocean surface, sea spray aerosols (SSA), with an emission estimate of 2-100 Pg per year, offer another large active surface area in the marine environment. 5 ,6 They are produced directly at the sea surface by bubble bursting and breaking waves, containing a large fraction of the organic compounds found in the SML. ${ }^{7,8}$ These interfaces are clearly enriched in dissolved organic matter (DOM) with some of these compounds, called chromophoric dissolved organic matter (CDOM), containing carbonyl functions, some aromatics with multiple double bonds which is conferring them the capacity of absorbing light. ${ }^{9-11}$ Such compounds will act as photosensitizers by absorbing irradiation and transferring this energy to other compounds, which are photochemically inactive. ${ }^{7,12}$ Previous studies have shown that such photosensitized processes can lead to the production and emission of volatile organic compounds (VOCs) from the air-sea interface, ${ }^{13-17}$ which are potential precursors for secondary organic aerosol (SOA) formation. 
Halide anions $\left(\mathrm{Cl}^{-}, \mathrm{Br}^{-}, \mathrm{I}^{-}\right)$are present in seawater, ${ }^{18}$ in the SML and in marine aerosols. ${ }^{19,20}$ Previous studies have shown that the aqueous phase oxidation of halides can take place through an electron transfer from the halide anion to the excited state of a photosensitizer (e.g., aromatic ketones), but never reported the production of gas phase products. The formation of reactive halogen atoms will have an important role for the aqueous phase reactivity, and one could speculate that they may lead to the formation of halogenated compounds that may partially degas in the air aloft. ${ }^{21-23}$ Such halogen-containing compounds play an important role in both tropospheric and stratospheric chemistry, destroying ozone through catalytic cycles, influencing hydroxyl radical chemistry, and affecting NOx concentrations. ${ }^{24}$ Moreover, they can trigger new particle formation, ${ }^{25,26}$ potentially affecting the evolution of cloud condensation nuclei $(\mathrm{CCN}),{ }^{19}$ and thus, indirectly climate processes. In addition, some of these halogenated products might also be toxic, impacting human health. It is therefore important to characterize the chemistry leading to their production in the marine environment.

It is believed that a large number of these short-lived brominated and iodinated organic substances are produced by algae ${ }^{27,28}$ in response to various environmental stresses. However, here we explore another chemical route in which those gaseous molecules are efficiently produced from photosensitized reactions at the ocean surface involving proxies of natural CDOM. Gaseous products were monitored by a novel online high-resolution mass spectrometry approach.

For the detection of halogenated VOCs an Orbitrap mass spectrometer (Q-exactive, Thermo Scientific) was equipped with a modified atmospheric pressure chemical ionization (APCI) source, using a corona discharge for the production of primary reagent ions. This technique combines the 
advantages of online measurements and the high mass resolution $(R=140 \mathrm{k}$ at $\mathrm{m} / \mathrm{z} 200)$ and high mass accuracy $(<3 \mathrm{ppm})$ of Orbitrap MS. The online analysis avoids potential sampling artifacts common to offline methods, such as evaporation, reaction during sample collection and analysis times. Moreover, since gas-phase compounds are analyzed in or close to real time by this method, it is possible to obtain time profiles with a high time resolution for a variety of halogenated compounds in parallel, which is in particular crucial for the detection of rather short-lived compounds. We note that, so far, only few techniques are available offering online analysis of gasphase organohalogens with such high accuracy.

Since the original ion source is designed for the analysis of liquid samples, the probe was modified according to Hoffmann and co-workers ${ }^{29}$, i.e., the sampling tube was removed (Figure S1). The ion source parameters were optimized for improved detection of VOCs and more especially halogenated VOCs while obtaining the best stability and sensitivity. For measurements in positive and negative modes the following settings were used, respectively: discharge voltage $+/-5 \mathrm{kV}$, capillary temperature $300 / 250^{\circ} \mathrm{C}$, sheath gas $1 / 0$ a.u., auxiliary gas $1 / 0$ a.u., maximum spray current $1 / 3.5 \mu \mathrm{A}$, and probe heater temperature $100 / 200^{\circ} \mathrm{C}$. The $\mathrm{Q}$ exactive Orbitrap mass spectrometer was mass calibrated before each analysis using a $2 \mathrm{mM}$ solution of sodium acetate. Analysis were conducted within a range of $50-750 \mathrm{~m} / \mathrm{z}$ and a resolution equal at 140000 at $\mathrm{m} / \mathrm{z}$ 200.

First, halogenated VOC standards were used to investigate the ionization behavior of such compounds. 1-bromopinacolone $\left(\mathrm{C}_{6} \mathrm{H}_{11} \mathrm{BrO}\right)$, benzoyl chloride $\left(\mathrm{C}_{7} \mathrm{H}_{5} \mathrm{ClO}\right)$ and 1,5-diiodopentane $\left(\mathrm{C}_{5} \mathrm{H}_{10} \mathrm{I}_{2}\right)$ were vaporized and analyzed under the conditions described above. In negative mode, clear signals for $\mathrm{Br}^{-}$and $\mathrm{I}^{-}$fragment ions were observed during the analysis of 1-bromopinacolone 
and 1,5-diiodopentane, respectively (Figure S2 \& Figure S3). Signals for $\mathrm{Cl}^{-}$ions (m/z 34.9694) were not detectable during the analysis of benzoyl chloride because of the lower mass range limit of the Orbitrap mass spectrometer (i.e., $\mathrm{m} / \mathrm{z} 50$ ). Additionally, during the analysis of bromopinacolone signals according to the deprotonated molecular ion $\left(\mathrm{C}_{6} \mathrm{H}_{10}{ }^{79} \mathrm{BrO}^{-}, \mathrm{m} / \mathrm{z}\right.$ 176.9920) including its isotopic pattern were observed (Figure 1). Nonetheless, signal intensities for molecular ions (i.e., $[\mathrm{M}-\mathrm{H}]^{-}$) in negative mode were generally lower by a factor of $\sim 10^{4}$ compared to corresponding $[\mathrm{M}+\mathrm{H}]^{+}$signals in positive ion mode. Halogenated organic compounds have apparently a best ionization in positive mode compare to negative mode in these conditions of APCI ionization.

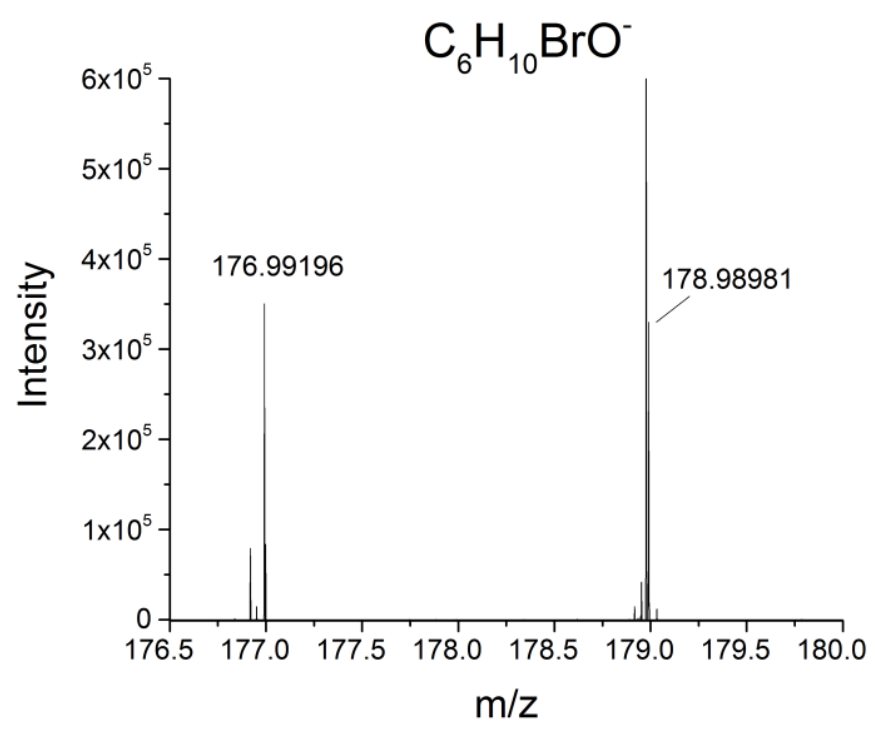

Figure 1. Mass spectrum of the analysis of 1-Bromopinacolone $\left(\mathrm{C}_{6} \mathrm{H}_{11} \mathrm{BrO}\right)$ in negative mode.

Analysis of the three standard compounds in positive mode yielded major signals at $\mathrm{m} / \mathrm{z}$ 179.0066 for bromopinacolone $\left(\left[\mathrm{C}_{6} \mathrm{H}_{11}{ }^{79} \mathrm{BrO}+\mathrm{H}\right]^{+}\right.$, Figure $\left.\mathrm{S} 4\right)$, at $\mathrm{m} / \mathrm{z} 141.0102$ for benzoyl chloride $\left(\left[\mathrm{C}_{7} \mathrm{H}_{5}{ }^{35} \mathrm{ClO}+\mathrm{H}\right]^{+}\right.$, Figure 2$)$ and at m/z 196.9821 for diiodopentane $\left(\mathrm{C}_{5} \mathrm{H}_{10} \mathrm{I}^{+}\right.$, Figure S5). 
As shown in these figures, isotopic patterns of chlorine and bromine were observed according to their natural abundance, further supporting the signal assignments.

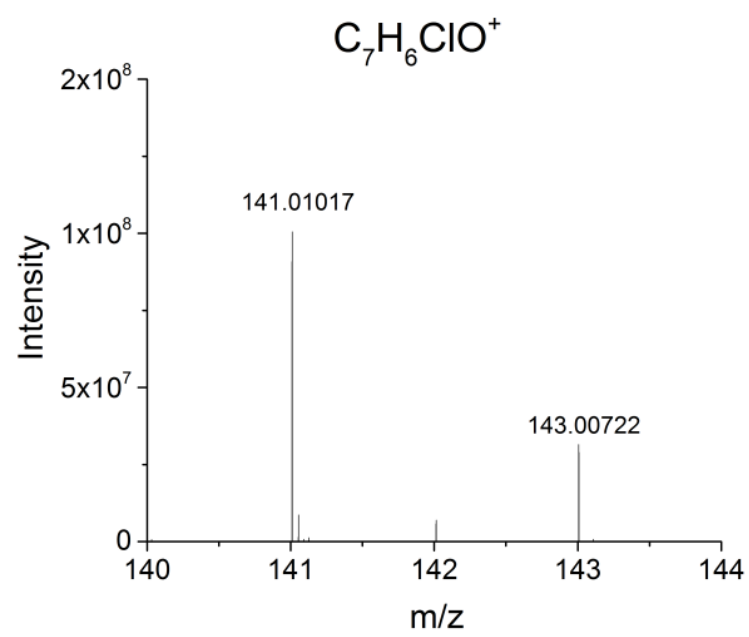

Figure 2. Mass spectrum of the analysis of benzoyl chloride $\left(\mathrm{C}_{7} \mathrm{H}_{5} \mathrm{ClO}\right)$ in positive mode. The isotopic pattern of chlorine is clearly visible for the signals at $\mathrm{m} / \mathrm{z} 141.0102\left(\left[\mathrm{C}_{7} \mathrm{H}_{5}{ }^{35} \mathrm{ClO}+\mathrm{H}\right]^{+}\right)$ and $\mathrm{m} / \mathrm{z} 143.0072\left(\left[\mathrm{C}_{7} \mathrm{H}_{5}{ }^{37} \mathrm{ClO}+\mathrm{H}\right]^{+}\right)$.

After validation of the developed online method for detection of volatile organohalogens, we applied it in photochemical experiments focusing on the detection and identification of halogenated organic compounds produced by photosensitized process. The irradiation experiments were performed using a quartz reactor $(2 \mathrm{~cm}$ diameter and $10 \mathrm{~cm}$ path length), half-filled with 14 $\mathrm{mL}$ of a synthetic sea-microlayer mixture. The final solution was composed of $1 \mathrm{M} \mathrm{NaCl}, 1 \mathrm{mM}$ $\mathrm{NaBr}, 1 \mu \mathrm{M} \mathrm{NaI}$ in $18 \mathrm{M} \Omega$ deionized water. A photosensitizer, 4-benzoylbenzoic acid (4-BBA), was added to simulate CDOM under realistic conditions; 4-BBA was therefore mixed with the previous solution to reach $0.1 \mathrm{mM}$. Depending on the actual experiments, 1-octanol was deposited on the surface of the solution to mimic the presence of a surfactant film (i.e., a final concentration 
of $\sim 2 \mathrm{mM}$ ). A Xenon arc lamp (150 W Xe, LOT-QuantumDesign France) was placed at a distance of $13 \mathrm{~cm}$ from the reactor to simulate actinic irradiation. A water filter was mounted in front of the lamp to remove infrared light to avoid heating. In addition, a Pyrex filter was added between the reactor and the lamp to remove short wavelengths $(<290 \mathrm{~nm})$ to be close to actinic conditions (Figure S6 and S7). A flow of $100 \mathrm{~mL} \cdot \mathrm{min}^{-1}$ of synthetic air was passed through this reactor and its composition was analyzed by APCI-Orbitrap-MS (Figure S7).

4-benzoylbenzoic acid (4-BBA), was chosen as a proxy for CDOM under realistic conditions, as we show in our previous investigations that such aromatic ketones, authentic sea-surface biofilms ${ }^{13}$ and products arising for the cell lysis ${ }^{15}$ do exhibit similar photochemical behavior. Also, Canonica et al. ${ }^{12}$ compared the relative behavior of aromatic ketones and various (commercial and standard) DOM material, and showed that overall that the DOM solutions have very similar kinetic selectivity as compared to the aromatic ketones, with almost identical rate constants. Therefore, 4BBA is a reasonable proxy for DOM especially in the context of this investigation, which aims at highlighting the usefulness of the novel APCI Orbitrap MS.

Figure 3a. shows typical chronograms of signals for $\mathrm{I}^{-}$fragment ions from gas-phase halogenated VOCs, in negative mode, during the irradiation of a solution containing the halides and 4-BBA in absence of any surfactant under synthetic air and nitrogen. 

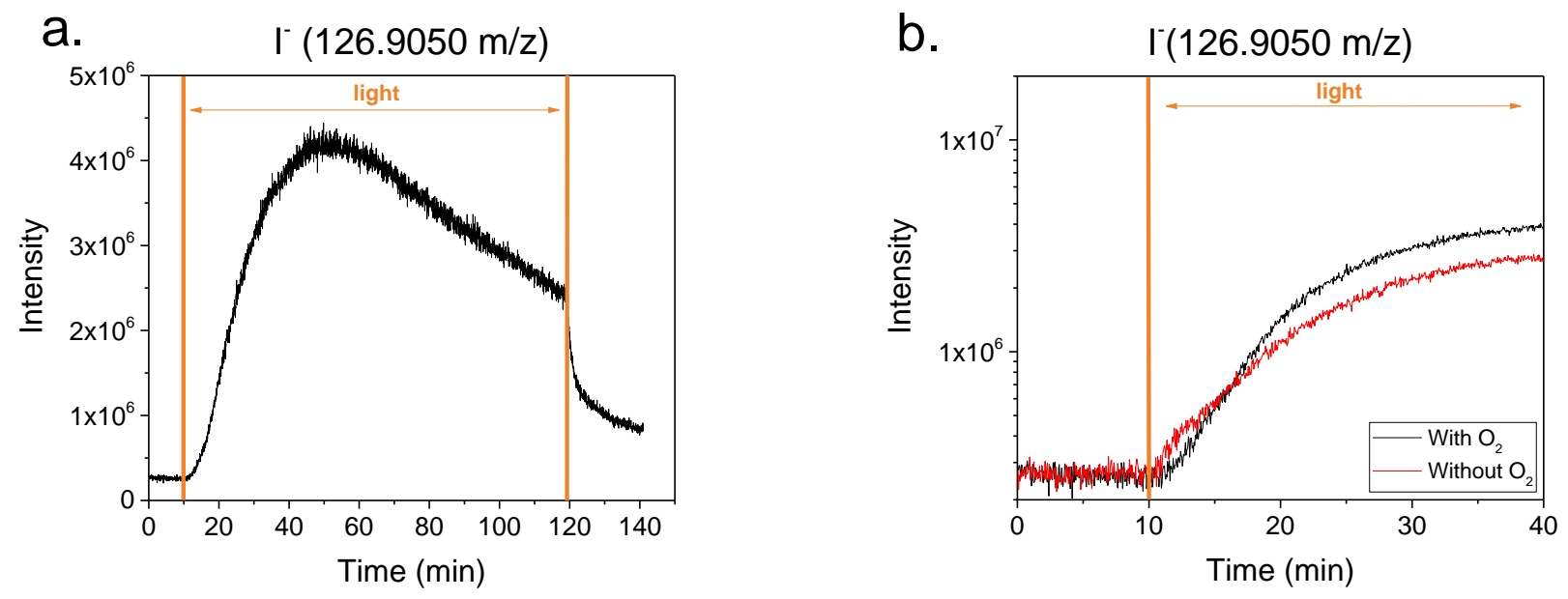

Figure 3. APCI-HRMS signals for $\mathrm{I}^{-}$in negative ion mode from a typical irradiation experiment under synthetic air (a) and under nitrogen (b.red line).

The production of $\mathrm{I}^{-}$is quickly increasing as soon as the light was turned on and reaching a maximum after about $40 \mathrm{~min}$, before slowly decaying again. However, as soon as the irradiation was turned off, the decrease accelerated and the ion signals for $\mathrm{I}^{-}$quickly dropped to background levels. Besides signals for $\mathrm{I}^{-}$, clear signals were also observed for $\mathrm{Br}^{-}\left({ }^{79} \mathrm{Br}^{-}\right.$at m/z $78.9189 \mathrm{~m} / \mathrm{z}$; ${ }^{81} \mathrm{Br}^{-}$at $\mathrm{m} / \mathrm{z}$ 80.9168, Figure S8) upon irradiation of the solution, generally exhibiting the same trends. These ion signals are clearly related to the fragmentation of halogenated VOCs in the ionization source. Figures 3 b. compares the initial growth rates of the $\mathrm{I}^{-}$fragment ions from gasphase halogenated VOCs, in negative mode, with (black line) and without oxygen (red line). It can clearly be seen that i) the production of halogenated VOCs as seen by the $\mathrm{I}^{-}$fragment is also taken place under oxygen free conditions, but ii) at significantly slower rate. Jammoul et $\mathrm{al}^{21}$ investigated the photoinduced oxidation of sea salt halides by aromatic ketones (i.e., benzophenone) as a source of halogenated radicals in deoxygenated solutions. They observed the production of the $\mathrm{I}_{2}^{-}$radical anion, and suggested a reaction mechanism in which the oxidation is initiated by an electron 
transfer from the halogenide anion $\mathrm{X}^{-}$to the excited triplet state of the aromatic ketone, yielding a halogen radical $\mathrm{X}^{*}$ and a deprotonated ketyl radical. Under oxygen free conditions, those radicals may undergo a series of recombination reactions yielding various halogenated products, whereas with oxygen the ketyl radical may produce various peroxy radicals boosting radical chains processes and potentially explaining the faster growth of products observed in Figure $3 b$.

In this study, when connecting an ultrafine Condensation Particle Counter (CPC) with a detection limit of $2.5 \mathrm{~nm}$ at the outlet of the photoreactor, we did not observe any particle formation despite that the fact that some of the identified VOC might act as aerosol precursor. There are two main reasons for that, firstly the timescale of the experiments is very short (seconds with respect to the gas phase residence time in the reactor), and secondly the (probably limited abundance) of the VOCs produced. Under such conditions, it is indeed unlikely that significant aerosol may take place and we solely observed the production of gaseous products.

In addition, complementary information on the production of halogenated organic compounds was obtained from positive mode analysis. Emission of chlorine-, bromine- and iodine-containing organic compounds was observed upon irradiation and molecular formulas were assigned to the compounds from the high-resolution mass spectra (Figure 4). All detected compounds exhibit at least one unsaturation and most of them are oxygenated (Table 1). Interestingly, the time behavior of these compounds differs significantly from each other, indicating the emission of multiple generation products (Figure S9 a-b). 


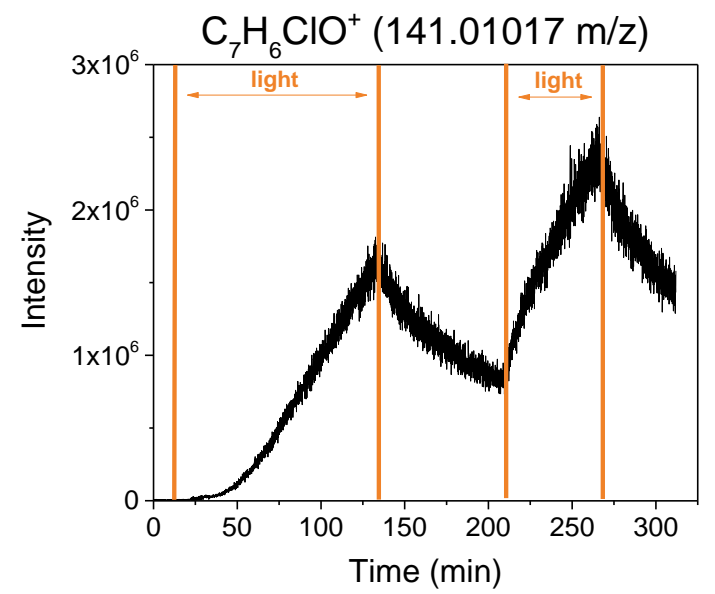

Figure 4. APCI-HRMS results from a typical irradiation experiment. The intensities of $\mathrm{C}_{7} \mathrm{H}_{6} \mathrm{ClO}^{+}$ in positive mode in the gas phase are plotted as a function of time.

Table 1. Compounds identified (detected D or not-detected ND) upon irradiation in presence of 4BBA, sea-salt halides with and without octanol by $(+)$ APCI-HRMS: detected mass, formula and degree of unsaturation.

\begin{tabular}{ccccc}
\hline $\begin{array}{c}\text { Detected } \\
\text { mass }(\mathrm{m} / \mathrm{z})\end{array}$ & $\begin{array}{c}\text { Formula of } \\
\text { neutral } \\
\text { compound* }\end{array}$ & Degree of unsaturation & $\begin{array}{c}\text { With } \\
\text { octanol }\end{array}$ & $\begin{array}{c}\text { Without } \\
\text { octanol }\end{array}$ \\
134.9441 & $\mathbf{C}_{3} \mathbf{H}_{3} \mathbf{B r O}$ & 2 & $\mathrm{ND}$ & $\mathrm{D}$ \\
141.0102 & $\mathbf{C}_{7} \mathbf{H}_{5} \mathbf{C l O}$ & 5 & $\mathrm{ND}$ & $\mathrm{D}$ \\
155.0259 & $\mathbf{C}_{\mathbf{8}} \mathbf{H}_{7} \mathbf{C l O}$ & 5 & $\mathrm{ND}$ & $\mathrm{D}$ \\
167.0259 & $\mathbf{C}_{9} \mathbf{H}_{7} \mathbf{C l O}$ & 6 & $\mathrm{ND}$ & $\mathrm{D}$ \\
181.0416 & $\mathbf{C}_{\mathbf{1 0}} \mathbf{H}_{9} \mathbf{C l O}$ & 6 & $\mathrm{ND}$ & $\mathrm{D}$ \\
182.9667 & $\mathrm{C}_{4} \mathrm{H}_{7} \mathrm{I}$ & 1 & $\mathrm{ND}$ & $\mathrm{D}$ \\
184.9459 & $\mathbf{C}_{3} \mathbf{H}_{5} \mathbf{I O}$ & 1 & $\mathrm{ND}$ & $\mathrm{D}$ \\
194.9667 & $\mathrm{C}_{5} \mathrm{H}_{7} \mathrm{I}$ & 2 & $\mathrm{D}$ & $\mathrm{ND}$ \\
\hline
\end{tabular}




\begin{tabular}{ccccc}
\hline 198.9614 & $\mathrm{C}_{4} \mathrm{H}_{7} \mathrm{IO}$ & 1 & $\mathrm{ND}$ & $\mathrm{D}$ \\
198.9752 & $\mathrm{C}_{8} \mathrm{H}_{7} \mathrm{BrO}$ & 5 & $\mathrm{ND}$ & $\mathrm{D}$ \\
212.9771 & $\mathrm{C}_{5} \mathrm{H}_{9} \mathrm{IO}$ & 1 & $\mathrm{D}$ & $\mathrm{D}$ \\
226.9928 & $\mathrm{C}_{6} \mathrm{H}_{11} \mathrm{IO}$ & 1 & $\mathrm{D}$ & $\mathrm{D}$ \\
231.1148 & $\mathrm{C}_{12} \mathrm{H}_{19} \mathrm{ClO}_{2}$ & 3 & $\mathrm{ND}$ & $\mathrm{D}$ \\
241.0085 & $\mathrm{C}_{7} \mathrm{H}_{13} \mathrm{IO}$ & 1 & $\mathrm{ND}$ & $\mathrm{D}$ \\
243.1148 & $\mathrm{C}_{13} \mathrm{H}_{19} \mathrm{ClO}_{2}$ & 4 & $\mathrm{ND}$ & $\mathrm{D}$ \\
255.0241 & $\mathrm{C}_{8} \mathrm{H}_{15} \mathrm{IO}$ & 1 & $\mathrm{D}$ & $\mathrm{D}$ \\
259.1097 & $\mathrm{C}_{13} \mathrm{H}_{19} \mathrm{ClO}_{3}$ & 4 & $\mathrm{ND}$ & $\mathrm{D}$ \\
287.0643 & $\mathrm{C}_{13} \mathrm{H}_{19} \mathrm{BrO}_{2}$ & 4 & $\mathrm{ND}$ & $\mathrm{D}$ \\
\hline *a mechanism is proposed for compounds in bold & &
\end{tabular}

Clearly, the information gathered by this novel APCI Orbitrap MS is rich in terms of (halogenated) product identification, and their changing time profiles. But, these data are also difficult to interpret in a quantitative manner as for most of the masses detected, there is a clear lack available commercial standards. Therefore, we can only, at this stage, speculate about the chemistry underlying our observations. Based, on previous observations, ${ }^{9,12,16}$ the initiation step is the known formation of the photosensitizer triplet state under irradiation. From this energetic state, the photosensitizer can then initiate charge exchange reactions with the halides, and especially with the most reactive one i.e., iodide..$^{21,22,30}$ This will produce atomic iodine, which in turn will initiate various known chain reactions producing mixed halogenated radical anions and atomic halogens ${ }^{21,22}$. In the presence of a large excess of $\mathrm{X}^{-}$, as in seawater, the corresponding halogen atom may react with the halogenide anion to produce the corresponding $\mathrm{X}^{*}{ }_{2}$ radical anions. Naturally, cross-reactions may take place producing the mixed dihalogen radical anion. Those halogenated radicals are strong oxidants and will react with most of the neighboring organic 
compounds (including the photosensitizing molecule), either by electron transfer and $\mathrm{H}-$ abstraction reactions. This would then produce a variety of organic radicals (alkyl, alkoxy, peroxy radicals in presence of oxygen), according to the following simplified reaction mechanism (where $\mathrm{T}$ is a given photosensitizer, $4 \mathrm{BBA}$ in this study and DOM in the real environment):

$$
\begin{array}{cc}
T+h v \rightarrow T^{*} & \text { R. } 1 \\
T^{*}+X^{-} \rightarrow X+T & \text { R. } 2 \\
X^{-}+X(\text { or } Y) \rightarrow X_{2}{ }^{-}\left(\text {or } X Y^{-}\right) & \text {R. } 3 \\
X+R H \rightarrow R+H X & \text { R. } 4
\end{array}
$$

( $R H$ is any neighboring organic compounds)

$$
\begin{aligned}
& R+R \rightarrow R_{2} \quad \text { R.5 } \\
& \mathrm{R}+\mathrm{O}_{2} \rightarrow \mathrm{RO}_{2} \quad \text { R.6 } \\
& \mathrm{RO}_{2}+\mathrm{X} \rightarrow \text { products } \quad \mathrm{R} .7
\end{aligned}
$$

The production of halogenated and organic radicals is inducing a rich and complex chemistry where a multitude of radical recombination reactions may take place. These reactions would correspond to the halogen-halogen or organic radicals recombination reactions. In the specific case of $4 \mathrm{BBA}$, a cleavage of a $\mathrm{C}-\mathrm{C}$ bond adjacent to the carbonyl function is possible, leading to the formation of various radicals (e.g., radical, phenylic radicals $\mathbf{1}$ and $\mathbf{2}$ in Scheme S1). Scheme S1, which tends to explain our observations, is still very speculative at this stage but it explains most of the products listed in Table 1, through a complex free-radical chemistry in the bulk solution, which is readily initiated by CDOM proxies upon irradiation. 
Under natural conditions, sea salt halides, DOM, and surfactants coexist at the sea surface. ${ }^{1}$ To understand the impact of surfactants on the production of halogenated VOCs, we used 1-octanol as a surfactant proxy and repeated the photochemical experiments under the same conditions.

Generally, in presence of octanol on the surface of the solution, a smaller number of halogenated compounds was detected compared to experiments without the surfactant (Table 1), while as expected oxygenated organic products were observed. ${ }^{13,14}$ In presence of an organic surfactant, 4BBA has been shown to migrate from the bulk aqueous phase to the interfacial rather organic-like phase. ${ }^{31}$ Thus, the bulk water is impoverished in the photosensitizer, explaining partly the reduced emission of halogenated products, as Scheme S1 is not specific to the interface. Obviously, the addition of a second organic reactant, i.e., 1-octanol, initiates a competition between the photosensitizer and the halogenated radicals that will alter the distribution of observable products. In addition, the oxidation products of 1-octanol might be more soluble, further changing the emission pattern of volatile compounds.

Interestingly, some of the reactions are clearly favored by the addition of the surfactant. In particular, iodine-containing VOCs with several carbon atoms exhibit much stronger emissions upon octanol addition. For example, for compounds such as $\mathrm{C}_{5} \mathrm{H}_{9} \mathrm{IO}, \mathrm{C}_{6} \mathrm{H}_{11} \mathrm{IO}$, and $\mathrm{C}_{8} \mathrm{H}_{15} \mathrm{IO}$, enhancement factors of 10 to 100 were observed in the corresponding ion signals. Moreover, signals for the iodine-containing compound $\mathrm{C}_{5} \mathrm{H}_{7} \mathrm{I}$ were solely observed in presence of octanol. As substitution of $\mathrm{Cl}$ by I is typically slightly increasing aqueous solubility, this cannot explain this drastic change in emission. ${ }^{32}$ This points to some surface specific process. Iodine atoms will not undergo $\mathrm{H}$-abstraction reactions, as compared to $\mathrm{Cl}$ and to some extent to $\mathrm{Br}$ atoms, but might be 
engaged into radical recombination reactions producing less polar products enriched at the interface (this has been observed for 4-BBA ${ }^{31}$ ), enhancing their emission into the gas phase.

In summary, multiple generations halogenated VOCs are produced upon irradiation of mimics of seawater containing CDOM. The triplet state induced production of halogenated radicals leads to complex chemistry that enhances the degassing of iodine-containing VOCs in presence of a surfactant. This is especially interesting as such short-lived halogenated substances might have an impact on the air quality and particle formation ${ }^{33-35}$.

\section{ASSOCIATED CONTENT}

\section{Supporting Information.}

Experimental details, supplementary graphics from APCI-Orbitrap analysis, mechanism. The Supporting Information is available free of charge on the ACS Publications website.

\section{AUTHOR INFORMATION}

\section{Corresponding Author}

*E-mail: christian.george@,ircelyon.univ-lyon1.fr

\section{Notes}

The authors declare no competing financial interests.

\section{ACKNOWLEDGMENT}

This study was supported by the European Research Council under the European Union's Seventh Framework Program (FP/2007-2013) / ERC Grant Agreement 290852 - AIRSEA, and the Region 
Auvergne Rhone Alpes. This project has received funding from the European Union's Horizon

2020 research and innovation programme under grant agreement No 690958

\section{REFERENCES}

(1) Liss, P. S.; Duce, R. A. The Sea Surface and Global Change; Cambridge University Press, $1-4,2005$.

(2) Wurl, O.; Wurl, E.; Miller, L.; Johnson, K.; Vagle, S. Formation and Global Distribution of Sea-Surface Microlayers. Biogeosciences 2011, 8 (1), 121-135. https://doi.org/10.5194/bg8-121-2011.

(3) Cunliffe, M.; Engel, A.; Frka, S.; Gašparović, B.; Guitart, C.; Murrell, J. C.; Salter, M.; Stolle, C.; Upstill-Goddard, R.; Wurl, O. Sea Surface Microlayers: A Unified Physicochemical and Biological Perspective of the Air-ocean Interface. Prog. Oceanogr. 2013, 109, 104-116. https://doi.org/10.1016/j.pocean.2012.08.004.

(4) Wurl, O.; Ekau, W.; Landing, W. M.; Zappa, C. J. Sea Surface Microlayer in a Changing Ocean - A Perspective. Elem Sci Anth 2017, 5 (0). https://doi.org/10.1525/elementa.228.

(5) de Leeuw Gerrit; Andreas Edgar L; Anguelova Magdalena D.; Fairall C. W.; Lewis Ernie R.; O’Dowd Colin; Schulz Michael; Schwartz Stephen E. Production Flux of Sea Spray Aerosol. Rev. Geophys. 2011, 49 (2). https://doi.org/10.1029/2010RG000349.

(6) Jayarathne, T.; Sultana, C. M.; Lee, C.; Malfatti, F.; Cox, J. L.; Pendergraft, M. A.; Moore, K. A.; Azam, F.; Tivanski, A. V.; Cappa, C. D.; et al. Enrichment of Saccharides and Divalent Cations in Sea Spray Aerosol During Two Phytoplankton Blooms. Environ. Sci. Technol. 2016, 50 (21), 11511-11520. https://doi.org/10.1021/acs.est.6b02988.

(7) Clark, C. D.; Zika, R. G. Marine Organic Photochemistry: From the Sea Surface to Marine Aerosols. In Marine Chemistry; The Handbook of Environmental Chemistry; Springer, Berlin, Heidelberg, 2000; pp 1-33. https://doi.org/10.1007/10683826_1.

(8) Blanchard, D. C. Jet Drop Enrichment of Bacteria, Virus, and Dissolved Organic Material. Pure Appl. Geophys. 1978, 116 (2-3), 302-308. https://doi.org/10.1007/BF01636887.

(9) McNeill, K.; Canonica, S. Triplet State Dissolved Organic Matter in Aquatic Photochemistry: Reaction Mechanisms, Substrate Scope, and Photophysical Properties. Environ. Sci. Process. Impacts 2016, 18 (11), 1381-1399. https://doi.org/10.1039/C6EM00408C.

(10) Sharpless, C. M.; Aeschbacher, M.; Page, S. E.; Wenk, J.; Sander, M.; McNeill, K. Photooxidation-Induced Changes in Optical, Electrochemical, and Photochemical Properties of Humic Substances. Environ. Sci. Technol. 2014, 48 (5), 2688-2696. https://doi.org/10.1021/es403925g.

(11) Cory, R. M.; McNeill, K.; Cotner, J. P.; Amado, A.; Purcell, J. M.; Marshall, A. G. Singlet Oxygen in the Coupled Photochemical and Biochemical Oxidation of Dissolved Organic Matter. Environ. Sci. Technol. 2010, 44 (10), 3683-3689. https://doi.org/10.1021/es902989y. 
(12) Canonica, S.; Jans, U.; Stemmler, K.; Hoigne, J. Transformation Kinetics of Phenols in Water: Photosensitization by Dissolved Natural Organic Material and Aromatic Ketones. Environ. Sci. Technol. 1995, 29 (7), 1822-1831. https://doi.org/10.1021/es00007a020.

(13) Ciuraru, R.; Fine, L.; Pinxteren, M. van; D’Anna, B.; Herrmann, H.; George, C. Photosensitized Production of Functionalized and Unsaturated Organic Compounds at the Air-Sea Interface. Sci. Rep. 2015, 5, 12741. https://doi.org/10.1038/srep12741.

(14) Fu, H.; Ciuraru, R.; Dupart, Y.; Passananti, M.; Tinel, L.; Rossignol, S.; Perrier, S.; Donaldson, D. J.; Chen, J.; George, C. Photosensitized Production of Atmospherically Reactive Organic Compounds at the Air/Aqueous Interface. J. Am. Chem. Soc. 2015, 137 (26), 8348-8351. https://doi.org/10.1021/jacs.5b04051.

(15) Brüggemann, M.; Hayeck, N.; Bonnineau, C.; Pesce, S.; A. Alpert, P.; Perrier, S.; Zuth, C.; Hoffmann, T.; Chen, J.; George, C. Interfacial Photochemistry of Biogenic Surfactants: A Major Source of Abiotic Volatile Organic Compounds. Faraday Discuss. 2017, 200 (0), 59-74. https://doi.org/10.1039/C7FD00022G.

(16) Kaur, R.; Anastasio, C. First Measurements of Organic Triplet Excited States in Atmospheric Waters. Environ. Sci. Technol. 2018, 52 (9), 5218-5226. https://doi.org/10.1021/acs.est.7b06699.

(17) Mungall, E. L.; Abbatt, J. P. D.; Wentzell, J. J. B.; Lee, A. K. Y.; Thomas, J. L.; Blais, M.; Gosselin, M.; Miller, L. A.; Papakyriakou, T.; Willis, M. D.; et al. Microlayer Source of Oxygenated Volatile Organic Compounds in the Summertime Marine Arctic Boundary Layer. Proc. Natl. Acad. Sci. U. S. A. 2017, 114 (24), 6203-6208. https://doi.org/10.1073/pnas.1620571114.

(18) Carpenter, L. J.; Nightingale, P. D. Chemistry and Release of Gases from the Surface Ocean. Chem. Rev. 2015, 115 (10), 4015-4034. https://doi.org/10.1021/cr5007123.

(19) Finlayson-Pitts, B. J. The Tropospheric Chemistry of Sea Salt: A Molecular-Level View of the Chemistry of $\mathrm{NaCl}$ and $\mathrm{NaBr}$. Chem. Rev. 2003, 103 (12), 4801-4822. https://doi.org/10.1021/cr020653t.

(20) Simpson, W. R.; Brown, S. S.; Saiz-Lopez, A.; Thornton, J. A.; Glasow, R. von. Tropospheric Halogen Chemistry: Sources, Cycling, and Impacts. Chem. Rev. 2015, 115 (10), 4035-4062. https://doi.org/10.1021/cr5006638.

(21) Jammoul, A.; Dumas, S.; D’Anna, B.; George, C. Photoinduced Oxidation of Sea Salt Halides by Aromatic Ketones: A Source of Halogenated Radicals. Atmos Chem Phys 2009, 9 (13), 4229-4237. https://doi.org/10.5194/acp-9-4229-2009.

(22) Tinel, L.; Dumas, S.; George, C. A Time-Resolved Study of the Multiphase Chemistry of Excited Carbonyls: Imidazole-2-Carboxaldehyde and Halides. Comptes Rendus Chim. 2014, 17 (7-8), 801-807. https://doi.org/10.1016/j.crci.2014.03.008.

(23) Parker, K. M.; Mitch, W. A. Halogen Radicals Contribute to Photooxidation in Coastal and Estuarine Waters. Proc. Natl. Acad. Sci. U. S. A. 2016, 113 (21), 5868-5873. https://doi.org/10.1073/pnas.1602595113.

(24) Seinfeld, J. H.; Pandis, S. N. Atmospheric Chemistry and Physics: From Air Pollution to Climate Change; John Wiley \& Sons, 317-323, 2016. 
(25) Ofner, J.; Kamilli, K. A.; Held, A.; Lendl, B.; Zetzsch, C. Halogen-Induced Organic Aerosol (XOA): A Study on Ultra-Fine Particle Formation and Time-Resolved Chemical Characterization. Faraday Discuss. 2013, $165 \quad$ (0), 135-149. https://doi.org/10.1039/C3FD00093A.

(26) Tsui, W. G.; Rao, Y.; Dai, H.-L.; McNeill, V. F. Modeling Photosensitized Secondary Organic Aerosol Formation in Laboratory and Ambient Aerosols. Environ. Sci. Technol. 2017, 51 (13), 7496-7501. https://doi.org/10.1021/acs.est.7b01416.

(27) Laturnus, F.; Svensson, T.; Wiencke, C. Release of Reactive Organic Halogens by the Brown Macroalga Saccharina Latissima after Exposure to Ultraviolet Radiation. Polar Res. 2010, 29 (3), 379-384. https://doi.org/10.3402/polar.v29i3.6075.

(28) Lim, Y.-K.; Phang, S.-M.; Sturges, W. T.; Malin, G.; Rahman, N. B. A. Emission of ShortLived Halocarbons by Three Common Tropical Marine Microalgae during Batch Culture. J. Appl. Phycol. 2018, 30 (1), 341-353. https://doi.org/10.1007/s10811-017-1250-z.

(29) Zuth, C.; Vogel, A. L.; Ockenfeld, S.; Huesmann, R.; Hoffmann, T. Ultrahigh-Resolution Mass Spectrometry in Real Time: Atmospheric Pressure Chemical Ionization Orbitrap Mass Spectrometry of Atmospheric Organic Aerosol. Anal. Chem. 2018, 90 (15), 8816-8823. https://doi.org/10.1021/acs.analchem.8b00671.

(30) Glover, C. M.; Rosario-Ortiz, F. L. Impact of Halides on the Photoproduction of Reactive Intermediates from Organic Matter. Environ. Sci. Technol. 2013, 47 (24), 13949-13956. https://doi.org/10.1021/es4026886.

(31) Tinel, L.; Rossignol, S.; Bianco, A.; Passananti, M.; Perrier, S.; Wang, X.; Brigante, M.; Donaldson, D. J.; George, C. Mechanistic Insights on the Photosensitized Chemistry of a Fatty Acid at the Air/Water Interface. Environ. Sci. Technol. 2016, 50 (20), 11041-11048. https://doi.org/10.1021/acs.est.6b03165.

(32) Sander, R. Compilation of Henry's Law Constants (Version 4.0) for Water as Solvent. Atmospheric Chem. Phys. 2015, $15 \quad$ (8), 4399-4981. https://doi.org/https://doi.org/10.5194/acp-15-4399-2015.

(33) Heald Colette L.; Jacob Daniel J.; Park Rokjin J.; Russell Lynn M.; Huebert Barry J.; Seinfeld John H.; Liao Hong; Weber Rodney J. A Large Organic Aerosol Source in the Free Troposphere Missing from Current Models. Geophys. Res. Lett. 2005, 32 (18). https://doi.org/10.1029/2005GL023831.

(34) Tsigaridis, K.; Daskalakis, N.; Kanakidou, M.; Adams, P. J.; Artaxo, P.; Bahadur, R.; Balkanski, Y.; Bauer, S. E.; Bellouin, N.; Benedetti, A.; et al. The AeroCom Evaluation and Intercomparison of Organic Aerosol in Global Models. Atmos Chem Phys 2014, 14 (19), 10845-10895. https://doi.org/10.5194/acp-14-10845-2014.

(35) Bernard, F.; Ciuraru, R.; Boréave, A.; George, C. Photosensitized Formation of Secondary Organic Aerosols above the Air/Water Interface. Environ. Sci. Technol. 2016, 50 (16), 8678-8686. https://doi.org/10.1021/acs.est.6b03520.

TOC figure 


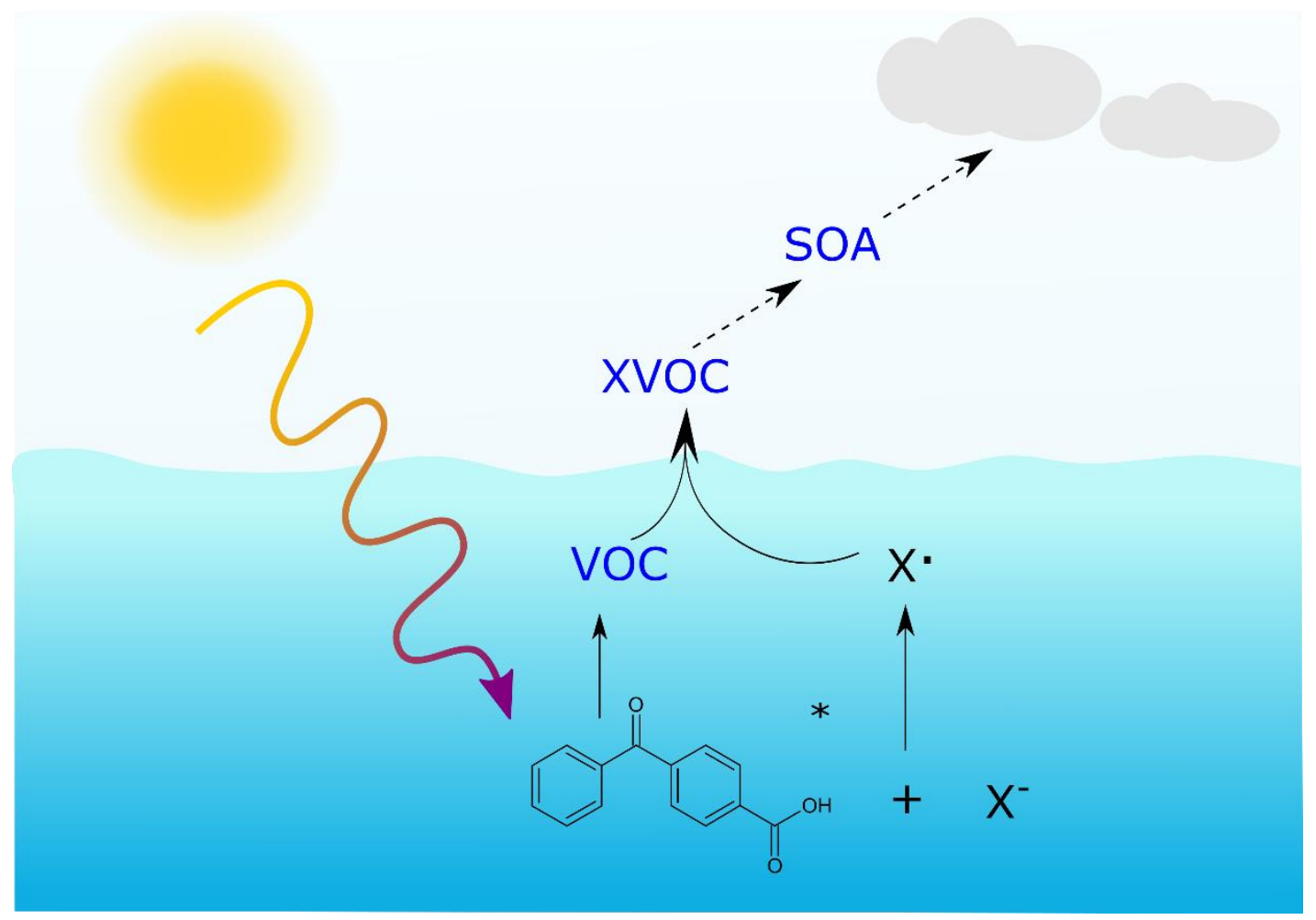

